\title{
Chemically-mediated rejection of dinoflagellate prey by the copepods Calanus pacificus and Paracalanus parvus: mechanism, occurrence and significance
}

\author{
M. Huntley, P. Sykes, S. Rohan \& V. Marin \\ Scripps Institution of Oceanography, A-002 La Jolla, California 92093, USA
}

\begin{abstract}
Thirteen species of dinoflagellates, ranging in size from 16 to $48 \mu \mathrm{m}$, were tested for particle rejection behavior in the copepods Calanus pacificus and Paracalanus parvus. Five dinoflagellates were rejected as food: Gonyaulax tamarensis (429), G. tamarensis (Ipswich), Ptychodiscus brevis, Scrippsiella trochoidea and Protoceratium reticulatum. The response of copepods to P. reticulatum was examined in detail. Starved copepods could not be induced to feed on this species; $C$. pacificus maintained in bloom concentrations ceased reproduction and had high mortality. Both the cells themselves and filtrate from the cell culture suppressed feeding on normally edible dinoflagellates. Direct observations showed that $P$. reticulatum cells cause reverse peristalsis and regurgitation, and that Ptychodiscus brevis cells cause elevated heart rate and loss of motor control by C. pacificus. We conclude the particle rejection behaviour we observed is chemically mediated, and that it may be an important factor in formation and maintenance of monospecific dinoflagellate blooms. We suggest chemicals produced by the dinoflagellate cause an acute physiological response which renders the herbivore incapable of ingesting more than required for its respiratory needs. Secondary effects of starvation, suspended reproduction and mortality further reduce the predation pressure of both present and future generations of predators. These factors aid in development of the bloom. Chemical defense may confer a competitive advantage, but rejected dinoflagellates pay the price in the form of reduced growth rates.
\end{abstract}

\section{INTRODUCTION}

Copepods are the most abundant Metazoa in the sea (Vinogradov 1970). They represent a major pathway for the flux of energy from primary producers to higher trophic levels (Conover 1978). Consumption of particulate matter by copepods has been shown to depend upon attributes of the particulate matter itself, namely (1) the size of particles and (2) the abundance of particles. Large particles are ingested with greater efficiency than small particles (Mullin 1963, Frost 1977. Runge 1980, Harris 1982). The relation of particle consumption to abundance follows a Holling Type II functional response (Holling 1965). At low concentrations particles are ingested in direct proportion to their abundance; at higher concentrations the functional response becomes saturated and ingestion rate remains constant or declines (Mullin 1963, Parsons et al. 1967, Frost 1972).
Thus many recent models of copepod grazing stipulate that only these 2 attributes of particulate matter size and abundance - affect its consumption (e.g. Lam \& Frost 1976, Steele \& Mullin 1977, Conover \& Huntley 1980, Huntley \& Boyd 1984). The implicit assumption in such models is that all particles, provided they are large enough to be captured, are subject to grazing.

This assumption is wrong, since it neglects the behavioral component of copepod feeding. Copepods are discriminating feeders. Recent studies show that they are able to select nutritious particles over nonnutritious particles of similar size and equal availability (e.g. Donaghay \& Small 1979). They capture, handle and reject (or ingest) particles according to particle quality.

One aspect of this behavior - 'particle rejection' has great potential significance in marine trophodynamics. It was first noted by Poulet \& Marsot (1978) who found that copepods rejected artificial microcap- 
sules containing seawater relative to those containing phytoplankton homogenate, Many studies followed, showing that copepods can reject a variety of inert particles, including plastic beads (Donaghay \& Small 1979), pollen grains (Fernandez 1979) and empty diatom frustules (Bartram 1980). Rejection of naturallyoccurring living particles was demonstrated by Huntley (1982), who showed Calanus pacificus rejected the yellow tide dinoflagellate, Gymnodinium flavum, giving preference to Thalassiosira weissflogii. Another dinoflagellate, Scrippsiella trochoidea (= Peridinium trochoideum) was later also shown to be rejected (Huntley et al. 1983).

Missing is a quantitative evaluation of those factors which determine the quality of particulate matter, and hence its availability to copepod grazers. We sought to address this problem by asking the following questions:

(1) What other, if any, dinoflagellates are rejected as food?

(2) How is particle rejection behavior influenced by the 'hunger', or degree of starvation, of copepod grazers?

(3) How does the relative abundance of 'low-quality' particles affect the ability of copepods to select and ingest 'high-quality' particles?

(4) What characteristics of dinoflagellates cause them to be rejected?

(5) How widespread is the rejection of dinoflagellates, and what ecological effects could this behavior cause?

The importance of these questions cannot be overemphasized. Any primary production rejected by copepod grazers would be available to other parts of the marine food web, such as (a) the microheterotrophic food web, already estimated to consume $60 \%$ of primary production (Williams 1981); other, less discriminating, pelagic grazers such as salps and appendicularia (Harbison \& McAlister 1979, Alldredge 1981); or (c) mesopelagic or benthic particle feeders, by sinking out of the photic zone. The results we present here suggest that rejection of dinoflagellates may strongly influence ecosystem dynamics.

\section{MATERIALS AND METHODS}

Dinoflagellate culture. Thirteen species of dinoflagellates were tested in our experiments. The species, their size, volume and carbon content are shown in Table 1. Size is reported as the maximum linear dimension of the cell; each value is the mean of 30 measurements on live cells, rounded to the nearest integer. Species ranged in size from $16 \mu \mathrm{m}$ (Gonyaulax
Table 1. Size (maximum width), volume, and carbon content of dinoflagellate species tested. Maximum widths are the mean of 30 measurements, rounded to the nearest integer Volume measurements are based on formulae for naked and thecate dinoflagellates (F. M. H. Reid, pers. comm.). Carbon content is the mean of 4 to 6 measurements of organic carbon (Sharp 1974) on samples from log-phase cultures

\begin{tabular}{|c|c|c|c|}
\hline Species & $\begin{array}{l}\text { Maximum } \\
\text { width } \\
(\mu \mathrm{m})\end{array}$ & $\begin{array}{l}\text { Volume } \\
\qquad\left(\mu \mathrm{m}^{3}\right)\end{array}$ & $\begin{array}{c}\text { Carbon } \\
\text { content } \\
\text { (ngC cell) }\end{array}$ \\
\hline Gonyaulax acatenella & 35 & 5500 & 3.98 \\
\hline Gonyaulax catenella & 16 & 530 & 0.41 \\
\hline Gonyaulax polyedra & 36 & 24900 & 8.90 \\
\hline Gonyaulax sphaeroidea & 35 & 22400 & 11.00 \\
\hline \multicolumn{4}{|l|}{ Gonyaulax } \\
\hline tamarensis (429) & 28 & 8800 & 2.51 \\
\hline \multicolumn{4}{|l|}{ Gonyaulax } \\
\hline tamarensis (Ipswich) & 30 & 9200 & 2.63 \\
\hline \multicolumn{4}{|l|}{ Gymnodinium } \\
\hline splendens (J83) & 44 & 19400 & 3.65 \\
\hline Gyrodinium dorsum & 34 & 10600 & 1.72 \\
\hline Gyrodinium resplendens & 31 & 12600 & 2.10 \\
\hline Peridinium foliaceum & 34 & 5300 & 1.23 \\
\hline \multicolumn{4}{|l|}{ Protoceratium } \\
\hline reticulatum & 48 & 16300 & 5.58 \\
\hline Ptychodiscus brevis & 28 & 4350 & 0.68 \\
\hline Scrippsiella trochoidea & 24 & 2340 & 0.62 \\
\hline
\end{tabular}

catenella) to $48 \mu \mathrm{m}$ (Protoceratium reticulatum), with the majority falling in the 30 to $40 \mu \mathrm{m}$ range.

Cell volumes (V) were calculated based on measurements of the length (A), width (B) and depth (C) of cells according to the general formula:

$$
V=(\pi / 6) \times A \times B \times C
$$

where $\mathrm{C}=1 / 3 \mathrm{~B}$ for thecate dinoflagellates and $\mathrm{C}=2 / 3$ $B$ for athecate dinoflagellates (F. M. H. Reid pers. comm.). An important criterion in choosing species for experiments was that they be nearly spherical, so that maximum length would approximate true size. Thus, spinose species such as Ceratium spp. were not used.

The carbon content of cells was measured directly following Sharp (1974). A 5 to $50 \mathrm{ml}$ aliquot of exponentially growing culture was filtered onto a precombusted GF/C filter at $<25 \mathrm{~cm} \mathrm{Hg}$, the filter rolled into an aluminium cylinder and placed in a desiccator at $-20^{\circ} \mathrm{C}$ until analysis could be performed. Three to 6 replicates were obtained for each species. The total amount of carbon present on each filter was determined by combustion in a Hewlett-Packard CHN analyser Triplicate $0.1 \mathrm{ml}$ aliquots of cell culture were counted on a Palmer-Maloney cell, yielding a measure of culture concentration which was used to calculate the carbon per cell.

Each dinoflagellate species was cultured at least twice from lag phase through stationary phase at 
approximately $15 \mathrm{klux}$, and at both 17 and $23^{\circ} \mathrm{C}$, to determine (a) generation time and (b) rate of exponential growth. These measurements permitted us to establish an optimum growth temperature and a transfer schedule which ensured that cells were always growing exponentially. Only exponentially-growing cells were used in subsequent feeding experiments. All species were cultured in Gonyaulax polyedra medium (Loeblich 1975).

Collection and pretreatment of experimental copepods. Copepods were collected $2 \mathrm{~km}$ from the coast of La Jolla, California $\left(32^{\circ} \mathrm{N}, 117^{\circ} \mathrm{W}\right)$ on numerous occasions between November 1982 and August 1984. Adult females of Calanus pacificus or Paracalanus parvus were sorted live and placed into a 2000 $\mathrm{ml}$ container filled with filtered seawater for several hours. All but two of the experiments discussed in this paper were conducted with $C$. pacificus.

For short-term ( 2 to $6 \mathrm{~h}$ ) feeding experiments the feeding condition of experimental copepods was standardized by prefeeding on saturating concentrations of Thalassiosira weissflogii for $48 \mathrm{~h}$, then placing in filtered seawater for $24 \mathrm{~h}$, both at 16 to $19^{\circ} \mathrm{C}$. This pretreatment procedure was followed for experiments conducted in 1982 and 1983. However, later experiments showed no difference between clearance rates of pretreated copepods and those used within $3 \mathrm{~h}$ after collection, so in subsequent experiments no pretreatment was used.

Particle rejection: experimental design. We used 2 types of experiments to determine whether or not a given dinoflagellate species is rejected as food. The first involves a cell-to-bead comparison, whereas the second involves a cell-to-cell comparison. The experimental protocol and subsequent statistical analysis depend upon which type of experiment is conducted.

In the first type of experiment the 'test' cell was offered in a mixture with particles known to be rejected (plastic beads: see Donaghay \& Small 1979, Huntley et al. 1983). The null hypothesis is that there is no significant difference between the mean clearance rates on the cell and the bead. Thus, a significant result (i.e. rejecting the original hypothesis) is a demonstration that the test cell is not rejected. To ensure that the experiment provided a rigorous test of the hypothesis we required that (a) the bead be as large as or larger than the test cell and (b) the test cell concentration be greater than that of the bead. Under these conditions one could not explain a greater clearance rate on the test cell as being due to the effects of either size or concentration (Frost 1972) - the result could be due only to particle quality.

The appropriate statistical test is a 1-tailed t-test for paired comparisons (Sokal \& Rohlf 1981). The test is for paired comparisons because each observation for one treatment (test cell) is paired with one from the other treatment (bead). A 1-tailed test is permitted because there is an a priori expectation that mean clearance rate on the cell will be greater than on the bead.

The second type of experiment was different; we compared the mean clearance rate on test cells to that on cells known to be acceptable as food (Gyrodinium resplendens). The cells were offered in separate suspensions, but at the same time and using the same stock of copepods. We consider the control cell, $G$. resplendens, to be acceptable as food because it is relatively small, yet yields high clearance rates and sustained egg production. The null hypothesis, using a 1-tailed t-test for the comparison of means (Sokal \& Rohlf 1981), is that the clearance rate on the test cell is equal to or greater than that on the control cell. Thus, a significantly lower clearance rate on the test cell statistically demonstrates that it is rejected. To ensure that the experiment would provide a rigorous test of the null hypothesis we required that (a) the test cell be approximately the same size or larger than G. resplendens and (b) the concentration of the test cell be less than that of $G$. resplendens.

Comparisons could not be made between clearance rates of copepods collected at different times of the year. This is because there was a significant change in the clearance rate with season, as Runge (1980) found for Calanus pacificus from Puget Sound. Fig. 1 shows how the clearance rate of $C$. pacificus females on Gyrodinium resplendens changed with season, compiling 181 independent measurements from separate experiments conducted between November 1982 and August 1984. Experimental conditions were identical in all cases, as described above, with initial particle

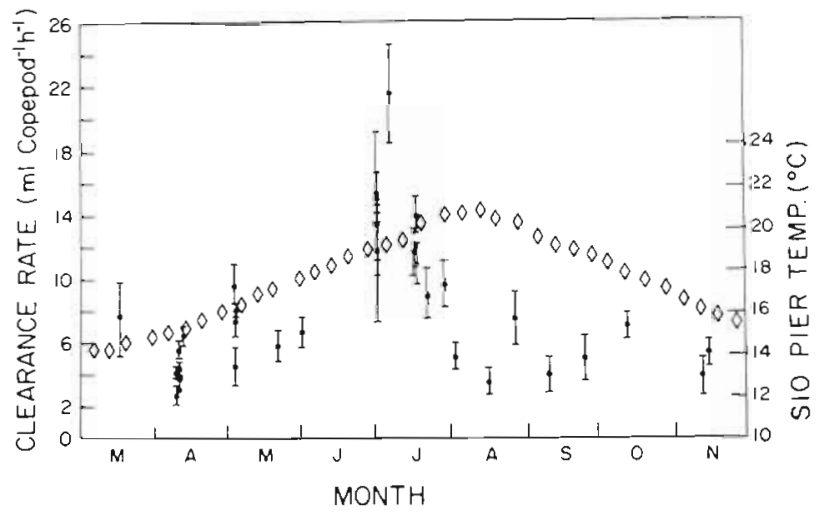

Fig. 1 Calanus pacificus. Seasonal variation in clearance rate $(\bullet)$ on the dinoflagellate Gyrodinium resplendens. Combined data from 23 experiments over a 3 yr period (1982-1984) show an increase during summer. Also shown is temperature of surface water sampled at Scripps Pier (0). Seasonal cycle shows weekly averages ot the $67 \mathrm{yr}$ mean, which range from 14 to $21^{\circ} \mathrm{C}$ during the period of the year $C$. pacificus was used in experiments 
concentrations in the range 40 to $300 \mu \mathrm{g} \mathrm{Cl} \mathrm{Cl}^{-1}$. Yet the mean clearance rate varied from as low as $2.74 \mathrm{ml}$ copepod ${ }^{-1} \mathrm{~h}^{-1}$ in the spring and fall to as high as 21.6 $\mathrm{ml}$ copepod $^{-1} \mathrm{~h}^{-1}$ in the summer. We suggest that clearance rate might have co-varied with the seasonal temperature cycle (Fig. 1).

Particle rejection: experimental conditions. Experimental suspension was poured into 4 to 6 replicate $280 \mathrm{ml}$ glass jars, adult female copepods were added (5 to 8 of Calanus pacificus, 15 of Paracalanus parvus), and the jars were placed on a $1 \mathrm{rpm}$ grazing wheel for 2 to $6 \mathrm{~h}$ under dim light ( $<0.02 \%$ of noon sunlight) at 16 to $19^{\circ} \mathrm{C}$. One or 2 control jars, not containing copepods, were run simultaneously.

Samples of suspension from each replicate were taken both before and after the experiment and were preserved in basic Lugol's solution. Abundances of particles in the samples were calculated as the mean of 2 to 5 replicate counts on an inverted microscope using the Utermöhl method (Lund et al. 1958). A thorough analysis of the sources of error in our sampling methodology was done to determine appropriate replication procedures; this study is separately reported in Marin et al. (in press).

Clearance rates were calculated from the difference between initial and final particle concentrations using the equation:

$$
F=\left[\left(\ln C_{0}-\ln C_{t}\right) \times V / t\right] / N
$$

where $\mathrm{F}=$ the clearance rate $\left(\mathrm{ml}\right.$ copepod $\left.{ }^{-1} \mathrm{~h}^{-1}\right) ; \mathrm{C}_{\mathrm{o}}$ $=$ the initial concentration (particles $\mathrm{ml}^{-1}$ ); $\mathrm{C}_{\mathrm{t}}=$ the final concentration in the experimental chamber (particles $\mathrm{ml}^{-1}$ ); $\mathrm{V}=$ the volume of the experimental chamber $(\mathrm{ml}) ; \mathrm{t}=$ the duration of the experiment $(\mathrm{h})$. Analysis of initial and final particle concentrations in control chambers showed no significant difference, presumably due mostly to the short experimental duration, so no correction for the growth of algae was necessary (cf. Frost 1972).

Hunger experiment. Protoceratium reticulatum was identified as a dinoflagellate repeatedly rejected as food by Calanus pacificus (see 'Results'), using the experimental procedures described above. We then addressed the question of whether hunger (starvation) could induce $C$. pacificus to feed on this cell which it ordinarily rejects. Specifically, we asked the following questions: (1) Do starved C. pacificus have higher clearance rates on an 'accepted' cell (Gyrodinium resplendens; $31 \mu \mathrm{m}, 2.1 \mathrm{ng} \mathrm{C}$ ) than on a rejected' cell ( $P$. reticulatum; $48 \mu \mathrm{m}, 5.6 \mathrm{ng} C$ )? (2) Do starved $C$. pacificus have higher daily rations on $P$. reticulatum than copepods which are fed?

Mixed zooplankton were collected in samples from La Jolla Bay on July 19, 1983. Adult female Calanus pacificus were sorted live into 3 'pretreatment' groups, each composed of 8 lots of 50 each. Each lot was then placed randomly in a separate 21 container of filtered seawater. Two of the 3 groups were maintained in filtered seawater. The third group was fed a suspension of $500 \mu \mathrm{g} \mathrm{C} 1^{-1}$ Gyrodinium resplendens. Both media were changed daily.

The experiment was run for $13 \mathrm{~d}$. At intervals of 12 , $48,72,120,168,216$ and 288 h we removed 1 lot of 50 copepods from each pretreatment group and conducted measurements as follows. First, the percent survival was calculated from counts of live and dead copepods in both the starved and fed conditions. Second, a grazing experiment was conducted using the survivors from each group, according to general procedures already described. One starved group was offered a suspension of Gyrodinium resplendens, the second was offered Protoceratium reticulatum. The pre-fed group was offered $P$. reticulatum. All grazing experiments were conducted for 2 to $3 \mathrm{~h}$ at equivalent initial concentrations ranging from 156 to $244 \mu_{\mathrm{g} \mathrm{Cl}} \mathrm{Cl}^{-1}$.

At the end of each grazing experiment particulate samples were preserved, and copepods were removed, dried to constant weight at $60{ }^{\circ} \mathrm{C}$, weighed (Lovegrove 1962), then combusted in a Hewlett-Packard CHN analyser to measure body carbon and nitrogen (Sharp 1974). Clearance rates were calculated from Eq. (2), and daily rations were calculated from the equation:

$$
T=\left[\left(F \times C_{0}\right) / W\right] \times 100
$$

where $T=$ the daily ration ( $\%$ body carbon $\left.\mathrm{d}^{-1}\right) ; \mathrm{F}=$ the clearance rate $\left(\mathrm{ml}\right.$ copepod $\left.{ }^{-1} \mathrm{~d}^{-1}\right) ; \mathrm{C}=$ the initial food concentration in the experiment $\left(\mu \mathrm{g} \mathrm{C} \mathrm{ml}^{-1}\right) ; \mathrm{W}=$ the carbon weight of the copepod ( $\mu \mathrm{g}$ body $\mathrm{C}$ copepod $^{-1}$ ).

Long-term feeding experiment. How might longterm exposure of Calanus pacificus to bloom concentrations of a rejected dinoflagellate affect survival and egg production? We addressed this question by conducting a long-term feeding experiment. Two groups of 75 adult females were sorted live from mixed zooplankton samples collected on August 27, 1983. The first group was maintained in a 2 I suspension of $500 \mu \mathrm{g}$ $\mathrm{C}^{-1}$ Protoceratium reticulatum.

We conducted the experiment for $27 \mathrm{~d}$ at $17^{\circ} \mathrm{C}$ under dim light. On each day we removed most of the suspension gently by reverse filtration, removed dead copepods, counted the survivors, and brought each container up to its original volume with fresh cell suspension. We also preserved a sample of the removed suspension and counted the number of eggs produced in the previous $24 \mathrm{~h}$.

Mixture experiment. Previous experiments indicated that Protoceratium reticulatum was a dinoflagellate of low nutritional value to Calanus pacificus. We then asked the question, 'How does the relative abundance 
of low-quality particles affect the ability of $C$. pacificus to ingest high-quality particles?'

Adult female Calanus pacificus were sorted live from samples collected in La Jolla Bay on August 27. 1983. Experimental suspensions were prepared with 7 different relative concentrations of Protoceratium reticulatum and Gyrodinium resplendens (the highquality particle), while maintaining total concentration constant at approximately $200 \mu \mathrm{g} \mathrm{Cl}^{-1}$ The grazing experiment was then conducted following general procedures already described. Clearance rates on both species were calculated from Eq. (2).

The chemical basis of particle rejection. Having established that the rejection of Protoceratium reticulatum cells could not be due to their size, shape or concentration (see 'Results'), we deduced that rejection must be due to chemical compounds produced by the cells themselves. We postulated that the bioactive compounds could reside either (a) intracellularly or (b) extracellularly. To examine this hypothesis we conducted an experiment in which we suspended equal concentrations of Gyrodinium resplendens cells in (1) filtered seawater, (2) filtrate from an exponentiallygrowing culture of $P$. reticulatum, and (3) homogenate of cells from the same culture.

Feeding experiments were conducted on 3 separate occasions (March 18, 1983; April 14, 1983; April 18, 1983) using general procedures already described. Clearance rates were calculated using Eq. (2), and the means were tested for significant difference using a 1 -tailed t-test at the 0.95 confidence level. Cell homogenate was tested for activity only in the March 18, 1983 experiment.

Hardy-Gunther exclusion hypothesis re-examined. Hardy \& Gunther (1936) noted that Antarctic zooplankton were virtually excluded from regions of high phytoplankton density, and they suggested this might be due to noxious substances exuded by the phytoplankton. The work of Fiedler (1982) lends recent support to this hypothesis with the finding that many species of zooplankton herbivores avoided a region of high density of Gymnodinium splendens in southern California waters.

We considered the possibility that substances produced by Protoceratium reticulatum might cause Calanus pacificus females to avoid bloom concentrations of the dinoflagellate. We conducted a series of experiments in which copepods were presented with the choice of locating themselves in one of the following environments: (1) filtered seawater, (2) 2000 cells $\mathrm{ml}^{-1}$ of Gyrodinium resplendens or (3) 2000 cells ml $^{-1}$ of $P$. reticulatum. Each experiment was conducted in a perspex chamber $30 \mathrm{~cm}$ long, $23 \mathrm{~cm}$ deep, and $2.5 \mathrm{~cm}$ wide. Each type of suspension was used sequentially to create the upper layer of a 2-layer aqueous system; the bottom layer was composed of filtered seawater colored with $1 \mathrm{mg} \mathrm{l}^{-1}$ rhodamine dye, so that layers could be easily distinguished. We established that the rhodamine dye did not affect copepod distributions. The density of the upper layer was reduced by diluting with $5 \%$ fresh water. Fifty copepods were then gently introduced, and 15 min were allowed for equilibration. All experiments were conducted at $18^{\circ} \mathrm{C}$ in a uniform light field at $10 \%$ of surface light intensity.

Each experiment was filmed for 10 min with a Sony 1800 video recorder fitted with a macro lens. Copepod distributions were evaluated from videotapes of the experiments by stopping the tape at randomly chosen intervals and counting the number of animals in each of the 2 experimental layers. Distributional data were evaluated using analyses of variance.

\section{RESULTS}

\section{Particles rejected}

The results of experiments in which we determined particle rejection by Calanus pacificus by comparing clearance rates on dinoflagellates and plastic beads are presented in Table 2. We found 7 of 10 species tested not to be rejected. In 6 independent experiments the remaining 3 species - Scrippsiella trochoidea, Gonyaulax tamarensis (429) and G. tamarensis - elicited clearance rates which were not significantly different from those on plastic beads, suggesting these species might be rejected.

Table 3 shows the results of experiments in which we determined particle rejection by Calanus pacificus by comparing clearance rate on a test dinoflagellate species to that on an acceptable food species, Gyrodinium resplendens. We found 3 of the 5 species tested to be rejected. The rejection of Ptychodiscus brevis and Scrippsiella trochoidea was established on the basis of 1 experiment apiece. However, for Protoceratium reticulatum we repeated this experiment 13 times on 5 separate days at 2 different seasons. Particle rejection was established in each case. The 2 remaining species - Gonyaulax catenella and Gyrodinium dorsum - produced clearance rates not significantly different from those on $G$. resplendens, indicating that these 2 species might not be rejected as food. The result with $G$. catenella corroborates our result from the cell/bead comparison (Table 2), in which we significantly showed this species is not rejected.

Table 4 shows the results of experiments in which we determined particle rejection by Paracalanus parvus by comparing the clearance rate on a test dinoflagellate to that on an acceptable dinoflagellate food (Gyrodinium resplendens). Of the 3 species we tested, 
Table 2. Calanus pacificus. Dinoflagellate species significantly shown not to be rejected. Test cells were mixed with beads of the same size. Requirements were that (1) the bead be as large or larger than the test cell, and (2) the test cell concentration be greater than that of the bead. A 1 -tailed t-test determined if clearance rate on the test cell was significantly greater than on the bead. Significance: $\cdots \mathrm{P}<0.05, \mathrm{NS}=$ not significant

\begin{tabular}{|c|c|c|c|c|c|}
\hline \multirow[t]{2}{*}{ Species } & \multirow[t]{2}{*}{ Date } & \multirow{2}{*}{$\begin{array}{c}\text { Test cell } \\
\text { initial conc. } \\
\left.\text { (ugC } ~^{-1}\right)\end{array}$} & \multicolumn{2}{|c|}{$\begin{array}{l}\text { Clearance rate } \\
\left(\mathrm{ml} \text { copepod }{ }^{-1} \mathrm{~h}^{-1}\right)\end{array}$} & \multirow[t]{2}{*}{ Significance } \\
\hline & & & Test & Control & \\
\hline \multicolumn{6}{|l|}{ Not rejected } \\
\hline Gonyaulax acatenella & 24 Nov 82 & 121 & 12.38 & 0 & $\cdots$ \\
\hline Gonyaulax catenella & 8 Nov 82 & 17 & 10.20 & 1.51 & $\cdots$ \\
\hline Gonyaulax polyedra & 23 Nov 82 & 146 & 10.42 & 0 & $\cdots$ \\
\hline Gonyaulax sphaeroidea & 6 May 83 & 145 & 5.60 & 1.55 & $\cdots$ \\
\hline Gyrodinium resplendens & 11 Sep 84 & 178 & 6.81 & 0.53 & $\cdots$ \\
\hline Peridinium foliaceum & 6 May 83 & 61 & 8.72 & 1.71 & $\cdots$ \\
\hline Gymnodinium splendens & 19 Aug 83 & 69 & 9.13 & 3.08 & $\cdots$ \\
\hline \multicolumn{6}{|l|}{ Rejected } \\
\hline Scrippsiella trochoidea & 9 Nov 82 & 61 & 5.44 & 5.04 & NS \\
\hline & 10 Nov 82 & 16 & 1.55 & 1.08 & NS \\
\hline & 30 Jul 84 & 53 & 1.28 & 1.32 & NS \\
\hline Gonyaulax tamarensis (429) & $20 \mathrm{Apr} 83$ & 123 & 2.34 & 3.79 & NS \\
\hline & $18 \mathrm{Jul} 84$ & 111 & 2.67 & 2.07 & NS \\
\hline Gonyaulax tamarensis (Ips) & 21 Apr 83 & 66 & 3.46 & 2.09 & NS \\
\hline
\end{tabular}

Table 3. Calanus pacificus. Dinoflagellate species significantly shown to be rejected. Test cells were offered separately with the control cell (Gyrodinium resplendens). Requirements were that (1) the test cell be as large or larger than the control, (2) the concentration of the test cell be less than that of the control and (3) both experiments be conducted on the same stock of copepods. A 1 -tailed t-test determined if clearance rate on the test cell was significantly less than on the control. Significance: ${ }^{-P} \mathrm{P}<0.05$. NS = not significant

\begin{tabular}{|c|c|c|c|c|c|}
\hline \multirow[t]{2}{*}{ Species } & \multirow[t]{2}{*}{ Date } & \multirow{2}{*}{$\begin{array}{c}\text { Test cell } \\
\text { initial conc. } \\
\left(\mu \mathrm{gC} \mathrm{l}^{-1}\right)\end{array}$} & \multicolumn{2}{|c|}{$\begin{array}{l}\text { Clearance rate } \\
\left(\mathrm{ml} \text { copepod } \mathrm{d}^{-1} \mathrm{~h}^{-1}\right)\end{array}$} & \multirow[t]{2}{*}{ Significance } \\
\hline & & & Test & Control & \\
\hline \multicolumn{6}{|l|}{ Rejected } \\
\hline \multirow[t]{13}{*}{ Protoceratium reticulatum } & 11 Apr 83 & 266 & 0.27 & 3.08 & $\cdots$ \\
\hline & & 234 & 0.27 & 2.74 & $\cdots$ \\
\hline & & 218 & 0.27 & 4.15 & $\cdots$ \\
\hline & $19 \mathrm{Jul} 83$ & 330 & 4.56 & 11.61 & $\cdots$ \\
\hline & $19 \mathrm{Jul} 83$ & 261 & 4.43 & 13.88 & $\cdots$ \\
\hline & & 228 & 4.74 & 10.82 & $\cdots$ \\
\hline & 18 Aug 83 & 214 & 2.28 & 3.52 & $\cdots$ \\
\hline & & 214 & 1.63 & 3.52 & $\cdots$ \\
\hline & $2 \mathrm{Jul} 84$ & 67 & 4.56 & 15.18 & $\cdots$ \\
\hline & & 155 & 3.51 & 11.65 & $\cdots$ \\
\hline & & 167 & 2.76 & 12.78 & $\cdots$ \\
\hline & & 211 & 4.59 & 14.84 & $\cdots$ \\
\hline & & 283 & 3.37 & 13.21 & $\cdots$ \\
\hline Ptychodiscus brevis & 1 Jun 84 & 40 & 3.09 & 6.59 & $\cdots$ \\
\hline Scrippsiella trochoidea & $30 \mathrm{Jul} 84$ & 152 & 2.79 & 9.48 & $\cdots$ \\
\hline \multicolumn{6}{|l|}{ Not rejected } \\
\hline Gonyaulax catenella & 8 Nov 82 & 79 & 5.54 & 5.48 & NS \\
\hline Gyrodinium dorsum & 8 Nov 82 & 79 & 3.54 & 5.48 & NS \\
\hline & 16 Nov 82 & 187 & 8.11 & 7.48 & NS \\
\hline
\end{tabular}


Table 4. Paracalanus parvus: Dinoflagellate species tested for significant rejection. Test cells were offered separately with the control cell (Gyrodinium resplendens). Other test conditions were the same as for Calanus pacificus (see Table 3). A 1-tailed ttest was done to determine if clearance rate on the test cell was significantly less than on the control. Significance: $\cdots$ P $<0.05$, NS $=$ not significant

\begin{tabular}{|c|c|c|c|c|c|}
\hline \multirow[t]{2}{*}{ Species } & \multirow[t]{2}{*}{ Date } & \multirow{2}{*}{$\begin{array}{c}\text { Control } \\
\text { Initial conc. } \\
\left(\mu \mathrm{gC}^{-1}\right)\end{array}$} & \multicolumn{2}{|c|}{$\begin{array}{c}\text { Clearance rate } \\
(\mathrm{ml} \text { copepod } \\
\left.-1 \mathrm{~h}^{-1}\right)\end{array}$} & \multirow[t]{2}{*}{ Significance } \\
\hline & & & Test & Control & \\
\hline \multicolumn{6}{|l|}{ Rejected } \\
\hline Protoceratium reticulatum & $14 \operatorname{Sep} 83$ & 95.8 & 2.06 & 3.24 & $\cdots$ \\
\hline \multicolumn{6}{|l|}{ Not rejected } \\
\hline Peridinium foliaceum & $14 \operatorname{Sep} 83$ & 95.8 & 3.33 & 3.24 & NS \\
\hline Gonyaulax tamarensis (429) & 14 Sep 83 & 95.8 & 3.24 & 3.24 & NS \\
\hline
\end{tabular}

only Protoceratium reticulatum was found to be rejected. We found no significant difference in the clearance rates of Gonyaulax tamarensis (429) or Peridinium foliaceum, relative to the clearance rate on G. resplendens, and thus we cannot conclude that either of these 2 species is rejected as food. This differs somewhat from the results for Calanus pacificus, which suggested that $G$. tamarensis might be rejected (Table $2)$ although in neither case does the statistical test allow a conclusive statement.
How does particle rejection quantitatively affect the physiology of the copepods we tested? Table 5 demonstrates quantitative effects on clearance rate and daily rations, based on the results of 16 independent determinations from 8 experiments. For each determination we calculated the clearance rate on the rejected dinoflagellate, expressed as a percentage of the clearance rate on Gyrodinium resplendens measured in the same experiment. For Calanus pacificus feeding on Protoceratium reticulatum this value ranged from 6.5 to

Table 5. Rejected dinoflagellates reduce copepod feeding rates. Clearance rates (from Tables 3 \& 4) of Calanus pacificus and Paracalanus parvus on rejected dinoflagellates are expressed as a percentage of clearance rate on the competent food, Gyrodinium resplendens, offered at the same time and at approximately the same initial concentration. Daily ration (\% dry body weight ingested $\mathrm{d}^{-1}$ ) is compared between the rejected species and $G$. resplendens, assuming $200 \mathrm{mg}$ dry weight for Calanus pacificus

\begin{tabular}{|c|c|c|c|c|}
\hline \multirow[t]{2}{*}{ Copepod } & \multirow[t]{2}{*}{ Rejected prey } & \multirow{2}{*}{$\begin{array}{c}\text { Clearance rate } \\
(\% \text { on Gyrodinium } \\
\text { resplendens })\end{array}$} & \multicolumn{2}{|c|}{ Daily ration $\left(\% \mathrm{~d}^{-1}\right)$} \\
\hline & & & $\begin{array}{l}\text { Rejected } \\
\text { prey }\end{array}$ & $\begin{array}{l}\text { Gyrodinium } \\
\text { resplendens }\end{array}$ \\
\hline \multirow[t]{15}{*}{ Calanus pacificus } & Protoceratium reticulatum & 8.8 & 1.2 & 26.8 \\
\hline & & 9.8 & 1.2 & 44.3 \\
\hline & & 6.5 & 1.2 & 25.8 \\
\hline & & 39.3 & 15.1 & 41.0 \\
\hline & & 31.9 & 20.8 & 109.0 \\
\hline & & 43.8 & 26.0 & 74.0 \\
\hline & & 46.3 & 8.5 & 22.6 \\
\hline & & 64.8 & 12.3 & 22.6 \\
\hline & & 30.0 & 8.1 & 30.3 \\
\hline & & 30.1 & 11.3 & 54.2 \\
\hline & & 21.6 & 11.2 & 64.2 \\
\hline & & 30.9 & 26.6 & 94.0 \\
\hline & & 25.5 & 28.7 & 112.1 \\
\hline & Ptychodiscus brevis & 46.9 & 4.4 & 7.9 \\
\hline & Scrippsiella trochoided & 29.4 & 8.4 & 43.3 \\
\hline \multirow[t]{2}{*}{ Paracalanus parvus } & Protoceratium reticulatum & 63.6 & nd & nd \\
\hline & Means: & 33.1 & $\overline{12.3}$ & $\overline{51.0}$ \\
\hline nd $=$ no data & & & & \\
\hline
\end{tabular}


$64.8 \%$, with a mean of $30.0 \%$. When fed Ptychodiscus brevis and Scrippsiella trochoidea, C. pacificus fed at 46.9 and $29.4 \%$ of the clearance rate on the control species. Similarly, the clearance rate of Paracalanus parvus on $P$. reticulatum was reduced to $63.6 \%$ of that on the control species. On average, the 2 copepod species had clearance rates on rejected dinoflagellates that were only $33.1 \%$ of the rates on the control species.

When feeding on rejected dinoflagellates, Calanus pacificus was barely able to meet its metabolic requirements. This is demonstrated by comparing the daily ration shown in Table 5 to the respiration rate of C. pacificus. Respiratory requirements at our experimental temperatures $\left(16\right.$ to $19^{\circ} \mathrm{C}$ ) range from approximately 7.5 to $10 \%$ dry body weight $\mathrm{d}^{-1}$, assuming 200 to $250 \mathrm{mg}$ dry body weight (Frost 1972, Runge 1980, data in this paper) and calculating respiration rate from equations of Huntley \& Boyd (1984). Daily rations of C. pacificus feeding on rejected dinoflagellates averaged $12.3 \% \mathrm{~d}^{-1}$, barely sufficient for respiration. By contrast, daily rations on Gyrodinium resplendens offered at equivalent concentrations averaged $51 \%$ $\mathrm{d}^{-1}$, leaving considerable energy for growth and reproduction.

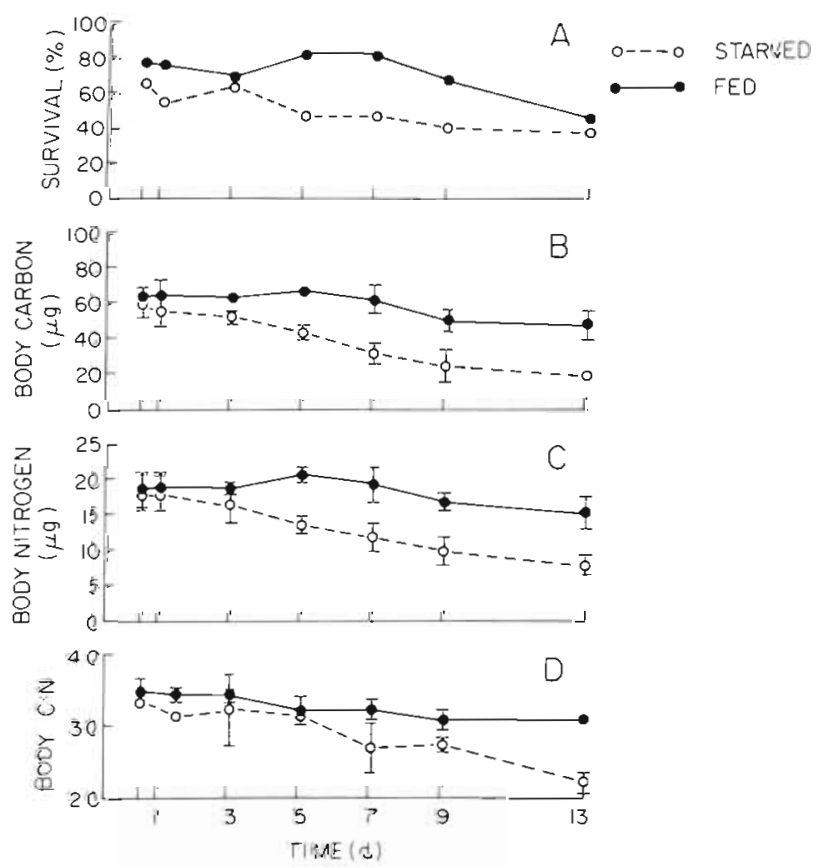

Fig. 2. Calanus pacificus. Comparative survival (A), body carbon (B) and nitrogen (C), and C:N ratio (D) of starved and fed females over a $13 \mathrm{~d}$ period. Starved copepods exhibited a significant decline in all parameters

\section{Hunger experiment}

Fig. 2 shows how important health indicators of Calanus pacificus responded to prolonged starvation, as compared to those of copepods continuously fed in a suspension of $500 \mu \mathrm{g} \mathrm{C} \mathrm{l}^{-1}$ Gyrodinium resplendens. Survival of starved copepods was lower than that of fed copepods, falling to $<40 \%$ after $13 \mathrm{~d}$. Body carbon content of starved copepods dropped from $60 \mu \mathrm{g}$ to $<20$ $\mu \mathrm{g}$; that of fed copepods decreased only to $51 \mu \mathrm{g}$. Similarly, body nitrogen of starved copepods fell from $18 \mu \mathrm{g}$ to $<8 \mu \mathrm{g}$. The body carbon:nitrogen ratio of starved copepods fell from 3.4 to 2.3 , whereas that of fed copepods decreased to only 3.1. In addition, we noted that after $7 \mathrm{~d}$ starvation, individuals were markedly lethargic as compared to those which were fed. Taken together, these are clear indications that non-feeding copepods were starving.

Fig 3 shows the daily rations and clearance rates of starved and fed copepods, measured at 6 intervals

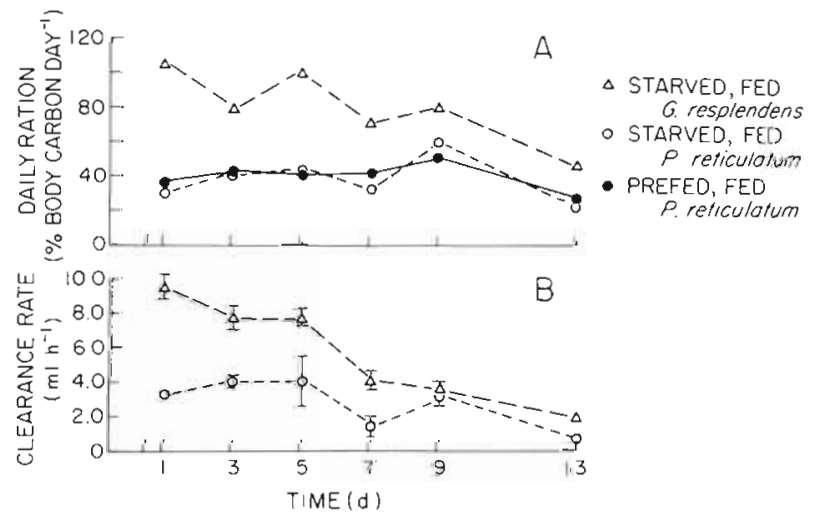

Fig. 3. Calanus pacificus. (A) Comparative daily rations of starved females fed either Gyrodinium resplendens $(\Delta)$ or Protoceratium reticulatum (O), and pre-fed females fed $P$. reticulatum (•). There is no significant difference in daily ration of starved and fed copepods on P. reticulatum. (B) Comparative clearance rates of starved females on $P$. reticulatum (O) and $G$. resplendens $(\Delta)$. Starvation did not induce copepods to increase consumption of $P$, reticulatum

during the experiment. Starved copepods had a higher clearance rate on Gyrodinium resplendens than on Protoceratium reticulatum (Fig. 3B), confirming our earlier results. The reduction in clearance rate was in part probably due to the loss of body weight. Daily ration normalizes for loss of body weight. Starved females offered $G$. resplendens always had a higher daily ration $(\overline{\mathrm{x}}=81 \%)$ than those offered $P$. ret $i$ culatum $(\overline{\mathrm{x}}=39 \%)$. More importantly, the daily ration of pre-fed copepods on $P$. reticulatum did not differ from that of starved copepods (Fig. 3A), indicating that starvation did not induce Calanus pacificus to increase its consumption of this rejected dinoflagellate. 


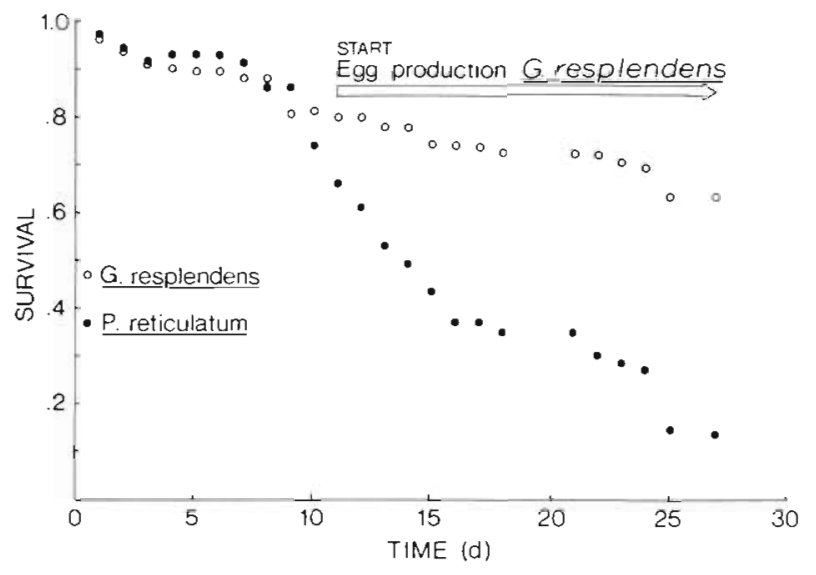

Fig. 4. Calanus pacificus. Comparative effects of bloom concentrations $\left(500 \mu \mathrm{g} \mathrm{C}^{-1}\right)$ of Protoceratium reticulatum and Gyrodinium resplendens on survival and egg production rate of adult females. Over a $30 \mathrm{~d}$ period, copepods exposed to $P$. reticulatum produced no eggs and experienced significantly greater mortality

\section{Long-term feeding experiment}

Two groups of 75 adult female Calanus pacificus were maintained for $27 \mathrm{~d}$ in suspensions of $500 \mu \mathrm{g} \mathrm{Cl}^{-1}$ of Gyrodinium resplendens and Protoceratium reticulatum, respectively. Survival and egg production rates for these 2 treatments are shown in Fig. 4 . No differences in survival were detected for the first 8 to $10 \mathrm{~d}$. Of the copepods in the $G$. resplendens treatment, $64 \%$ survived to the end of the experiment. By contrast, the survival of copepods in $P$. reticulatum declined precipitously after the tenth day, finally reaching only $13 \%$. On the eleventh day adult females in the $G$. resplendens treatment began producing eggs, and continued to do so until the end of the experiment. Females in the $P$. reticulatum treatment never produced eggs

Our observations indicate that copepods exposed to Protoceratium reticulatum for a prolonged period were starving. In addition to the high mortality rate and the absence of egg production, these animals produced very few fecal pellets and became conspicuously lethargic after about $10 \mathrm{~d}$. These results are similar to those observed for copepods purposely starved in filtered seawater.

\section{Mixture experiment}

The presence of Protoceratium reticulatum reduces the clearance rate on Gyrodinium resplendens when these 2 cells are offered in mixture, as shown by results in Fig. 5. The total particulate carbon concentration

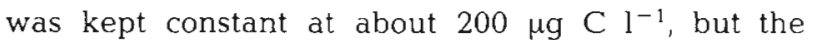
proportion of $P$. reticulatum was varied from 0 to $92 \%$.

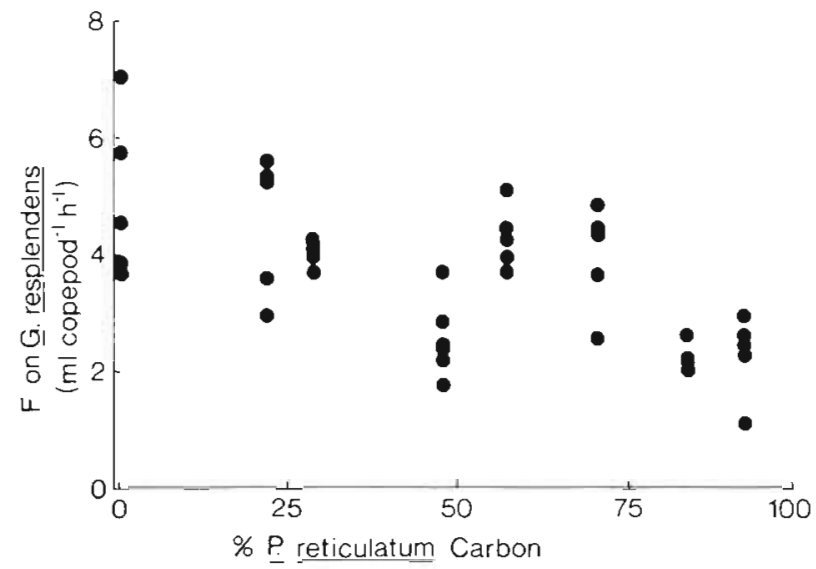

Fig. 5. Calanus pacificus. The presence of Protoceratium reticulatum suppresses feeding (F) on a normally edible dinoflagellate (Gyrodinium resplendens). The total cell concentration was kept constant at approximately $200 \mu \mathrm{g} \mathrm{Cl}^{-1}$ while varying the proportion of both cells in the suspension. As the proportion of $P$. reticulatum was increased the copepods removed edible cells at progressively lower rates

When $P$. reticulatum was absent the clearance rate on $G$. resplendens was high $\left(\overline{\mathrm{x}}=5.0 \mathrm{ml} \mathrm{h}^{-1}\right)$, but as the proportion of $P$. reticulatum rose the clearance rate on $G$. resplendens steadily declined, finally reaching 1.96 $\mathrm{ml} \mathrm{h}^{-1}$

Results presented earlier showed that the clearance rates on Protoceratium reticulatum were only $30 \%$ of those on Gyrodinium resplendens when the 2 species were offered separately (Table 5). Results in Fig. 5 demonstrate that some attribute of $P$. reticulatum is capable of reducing the clearance rate on $G$. resplendens to $<40 \%$ of normal when the cells are offered together. We reasoned that this effect might be due to a chemical constituent of $P$. reticulatum, either excreted or residing in the cell itself, which inhibits feeding. The next set of experiments addressed this hypothesis.

\section{Chemical basis of particle rejection}

Chemical compounds excreted by Protoceratium reticulatum are the causative agents in the rejection of this dinoflagellate by Calanus pacificus. We showed this in several experiments in which we suspended equal concentrations of Gyrodinium resplendens cells in either filtered seawater, filtrate from an exponentially-growing culture of $P$. reticulatum, or homogenate of cells from the same culture. The results of these experiments are shown in Table 6. In the first experiment, using an initial concentration of $99 \mu \mathrm{Cl}^{-1}$, we found no significant difference between clearance rates in filtered seawater and homogenate. However, clearance rate in the filtrate was only $49 \%$ of that in the filtered seawater control. 
Table 6. Protoceratium reticulatum. Results of experiments showing that inhibitory activity is produced extracellularly. Readilyingested control cells (Gyrodinium resplendens) were suspended in either (1) filtrate of $P$. reticulatum culture or (2) homogenate of $P$. reticulatum cells from the same culture. Clearance rates of Calanus pacificus were compared to control cells suspended in filtered seawater. A 1-tailed t-test determined if clearance rate in test suspensions was significanttly less than in filtered seawater suspensions. Significance: $\cdots \mathrm{P}<0.05, \mathrm{NS}=$ not significant

\begin{tabular}{|c|c|c|c|c|c|}
\hline \multirow[t]{2}{*}{ Test substrance } & \multirow[t]{2}{*}{ Date } & \multirow{2}{*}{$\begin{array}{c}\text { Control cell } \\
\text { initial conc. } \\
\left(\mu g \mathrm{Cl}^{-1}\right)\end{array}$} & \multicolumn{2}{|c|}{$\begin{array}{c}\text { Clearance rate } \\
\left(\mathrm{ml} \text { copepod } \mathrm{d}^{-1} \mathrm{~h}^{-3}\right)\end{array}$} & \multirow[t]{2}{*}{ Significance } \\
\hline & & & Test & Contral & \\
\hline Filtrate & $\begin{array}{l}18 \text { Mar } 83 \\
14 \text { Apr } 83 \\
18 \text { Apr } 83\end{array}$ & $\begin{array}{r}99 \\
179 \\
159\end{array}$ & $\begin{array}{l}3.72 \\
3.05 \\
1.62\end{array}$ & $\begin{array}{l}7.57 \\
6.39 \\
4.19\end{array}$ & $\begin{array}{l}\cdots \\
\cdots\end{array}$ \\
\hline Homogenate & 18 Mar 83 & 99 & 7.06 & 7.57 & NS \\
\hline Filtrate, aged $>24 \mathrm{~h}$ & 12 Apr 83 & 251 & 5.52 & 4.28 & NS \\
\hline
\end{tabular}

Results of 2 subsequent experiments confirmed activity of Protoceratium reticulatum filtrate. In the first, clearance rate was reduced to $48 \%$ of the control; in the second it was reduced to $39 \%$. Thus, chemical compounds excreted by $P$. reticulatum into its environment were capable, on average, of reducing clearance rates on a readily-ingested cell to $45 \%$ of normal. In all 3 experiments the cell concentration in cultures used to prepare the filtrate and homogenate was $<1,000$ cells $\mathrm{ml}^{-1}$, a concentration roughly representative of a bloom of this species. Further evidence that $P$. reticulatum excretes bioactive compounds is inferred from the observation that filtrate aged for more than $24 \mathrm{~h}$ loses its ability to suppress clearance rate (Table 6). 'Active' filtrates were produced and used in feeding experiments within $6 \mathrm{~h}$. Thus, the active chemical constituents of the filtrate may be reactive or volatile, and appear to degrade within 6 to $24 \mathrm{~h}$

\section{Hardy-Gunther exclusion hypothesis re-examined}

Exudates or excreted metabolites of Protoceratium reticulatum did not affect distributions of female Calanus pacificus in experimental 2-layer systems (Table 7). Copepods were presented with the choice of locating themselves within a lower layer of filtered seawater or an upper layer alternately composed of (1) filtered seawater, (2) 2000 cells ml-1 of Gyrodinium resplendens, or (3) 2000 cells $\mathrm{ml}^{-1}$ of $P$. reticulatum. We counted copepods in the upper layer from frames of the video-recording frozen at randomly-chosen intervals. Of the total of 50 copepods in each experiment, the mean number in the upper layer ranged only from 31.4 to 34.8 , regardless of its composition. When the upper layer was composed of filtered seawater an average of 31.4 copepods were found there, based on 20 observations. The mean numbers for $G$. resplendens and $P$. reticulatum were 34.2 and 34.8 , respectively; each calculation was based on 100 observations.

Analysis of variance on the experimental data (Table 7) demonstrated that the type of cell suspension had no significant effect on the distribution of Calanus pacificus.

\section{DISCUSSION}

\section{Occurrence of particle rejection}

How widespread is the phenomenon of particle behavior? Of the 13 species or strains of dinoflagellates we studied, 5 elicited particle rejection behavior by Calanus pacificus in a variety of tests. These were

Table 7. Distributions of Calanus pacificus in 2-layer chamber where the upper layer was composed of either (1) filtered seawater, (2) 2000 cells ml $\mathrm{m}^{-1}$ of Gyrodinium resplendens, or (3) $2000 \mathrm{cells} \mathrm{ml}^{-1}$ of Protoceratium reticulatum. Bottom layer was filtered seawater dyed with $1 \mathrm{mg} \mathrm{1^{-1 }}$ rhodamine. Data refer to the mean and variance of the numbers of copepods (out of 50) observed in the upper layer at $\mathrm{N}$ randomly chosen intervals

\begin{tabular}{|c|c|c|c|}
\hline & Filtered seawater & $\begin{array}{c}\text { Treatment } \\
2000 \text { cells } \mathrm{ml}^{-1} \\
\text { Gyrodinum resplendens }\end{array}$ & $\begin{array}{l}2000 \text { cells } \mathrm{ml}^{-1} \\
\text { Protoceratium reticulatum }\end{array}$ \\
\hline$N$ (no. observations) & 20 & 100 & 100 \\
\hline Mean copepods in upper lcyer & 31.4 & 348 & 34.2 \\
\hline Variance & 49.0 & 807 & 16.8 \\
\hline
\end{tabular}


Gonyaulax tamarensis (429), G. tamarensis (Ipswich), Ptychodiscus brevis, Scrippsiella trochoidea, and Protoceratium reticulatum. The latter species was also rejected by Paracalanus parvus. The first species, G. tamarensis, is responsible for prolonged and widespread fall blooms in the Gulf of Maine, the Bay of Fundy, and the coasts of western Canada, South America and Japan (Anderson et al. 1982, Steidinger 1983); the 429 strain reduces feeding rates in 5 species of copepods from coastal waters of Nova Scotia (Ives in press). The second species ( $P$. brevis) has caused numerous blooms in coastal waters of the southeastern United States and coastal waters of Japan (Iizuka 1975, Murphy et al. 1975, Steidinger 1983), and is known to produce a variety of potent neurotoxins (Baden et al. 1981, Lin et al. 1981). S. trochoidea is common in waters of the California Current, but is not known to cause widespread blooms (Allen 1941). P. reticulatum occurs off Australia and New Zealand, in the Caribbean (Wood 1968), and in coastal waters of northern Europe (E. Sakshaug pers. comm.). Neither of the 2 latter species are known to produce toxic metabolites.

We established particle rejection of both strains of Gonyaulax tamarensis, based on 3 separate occasions when they were fed upon at clearance rates not significantly different than those on plastic beads. Evidence for Ptychodiscus brevis is based on 1 experiment in which the clearance rate was significantly lower than on the competent food cell, Gyrodinium resplendens. Evidence for Scrippsiella trochoidea is based on both types of experiments conducted on 4 separate occasions; this reinforces previous findings (Huntley et al. 1983). We repeatedly confirmed rejection of $P$. reticulatum, finding - in 13 independent experiments - a significantly lower clearance rate than on $G$. resplendens.

The particle rejection behavior we observed cannot be explained by effects of shape, size or concentration of particles. The shape of the dinoflagellate species we tested ranged from the almost perfect sphere (Gonyaulax sphaeroidea) to the oblate or ellipsoid sphere (Peridinium foliaceum). Species with markedly nonspherical shapes were avoided, since copepods may feed upon them as if they were larger (Gifford et al. 1981). The relative size of particles in our experimental comparisons was adjusted to account for Frost's (1972) observation of higher grazing efficiency on larger particles. For example, we used the cell/cell comparison between Protoceratium reticulatum $(48 \mu \mathrm{m})$ and Gyrodinium resplendens $(31 \mu \mathrm{m})$ because size considerations predict the larger cell will be removed more efficiently. Thus, the finding that $P$. reticulatum actually was removed at a lower rate than the small cell cannot be due to the effect of size. The relative concentration of particles in our experiments was adjusted to account for the phenomenon of reduced clearance rate at higher particle concentrations (Mullin 1963, Frost 1977, Harris 1982). For example, we presented $P$. reticulatum at a lower concentration than $G$. resplendens because concentration effects would predict the least abundant cell will be removed at a greater rate. Thus, the finding that $P$. reticulatum actually was removed at a lower rate cannot be due to effects of particle concentration.

Feeding history cannot explain particle rejection behavior. During the first 2 yr of experiments, feeding history of copepods was standardized by feeding for $48 \mathrm{~h}$ on superabundant Thalassiosira weissflogii, then starving for $24 \mathrm{~h}$ in filtered seawater. Yet particle rejection was observed. Furthermore, we found starved copepods had the same daily ration on Protoceratium reticulatum as copepods pre-fed for up to $13 \mathrm{~d}$ on Gyrodinium resplendens.

If a large, quasi-spherical dinoflagellate cell such as Protoceratium reticulatum is repeatedly rejected as food by both starved and pre-fed copepods, then we can only conclude that it must be due to effects of something other than particle shape, size, concentration, or feeding history of the predator. We conclude that particle rejection behavior is chemically mediated.

\section{Mechanism}

Our experimental results suggest a physiological mechanism as the basis for particle rejection behavior. The stimulus is provided by chemical compounds produced, either intracellularly or extracellularly, by the dinoflagellate. The primary response of the predator is an acute physiological reaction which renders it incapable of feeding. Changes in behavior are secondary responses. Chemoreception does not appear to play a role in the mechanism.

We base our conclusions on observations of Calanus pacificus feeding on both Ptychodiscus brevis and, primarily, Protoceratium reticulatum. There are several reasons why the stimulus must be a chemical compound produced by the dinoflagellate. First, filtrates from the bioactive dinoflagellate cause normally edible cells to be rejected; in $P$. reticulatum the active constituents are most certainly excreted, but they may be intracellular in other dinoflagellates. Second, the presence of a bioactive dinoflagellate causes normally edible cells to be rejected; this effect suggests a chemical mechanism since it is a function of the proportion of bioactive cells present. Third, none of the experimental observations can be explained by known effects of particle shape, size, concentration, or predator feeding history. Finally, we directly observed physiological reactions of copepods which can only result from chemical stimuli. 
Evidence suggests that the reaction to bioactive dinoflagellates is an acute physiological event which renders the copepod predator incapable of feeding. First, copepods may starve to death rather than feed on a bioactive dinoflagellate. Second, cells of Protoceratium reticulatum and Ptychodiscus brevis cause, respectively, either regurgitation or elevated heart rate and loss of motor control (Sykes \& Huntley unpubl.). In both cases, normal feeding resumed when the copepod was placed in a suspension of Gyrodinium resplendens.

Thus, the particle rejection behavior we report may not be related to chemoreceptive abilities of the copepod. Strickler (1982) has suggested that copepods can detect the chemical properties of food particles and decide whether or not to eat them before they are ingested. This explanation requires that copepods have the necessary chemosensory apparatus, which apparently they do (Ong 1969, Friedman \& Strickler 1975, Barrientos 1980). Evidence for a behavioral response was presented by Paffenhofer et al. (1982), who interpreted high-speed films to 'indicate that copepods can track food particles'. The observation of Koehl \& Strickler (1981), that algal cells are usually redirected without actually being touched by the feeding appendages suggests a behavioral response to chemical stimuli.

Our observations suggest an additional mechanism. First. Calanus pacificus made its decision to eat, or not to eat, after ingestion. In all our observations the copepod always ingested some particles at the outset of the experiment - only later did it cease to feed entirely. Second, regurgitation, elevated heart rate, and loss of motor control are purely physiological reactions - they are not behavioral responses linked to chemoreception. We can only conclude that the mechanism for the particle rejection behavior we observed is chemically induced and that, in general, it renders the copepod incapable of feeding.

What chemical compounds might be responsible? We do not know However, they may not be compounds which are associated with the well-known toxicity of Paralytic Shellfish Poison (PSP) or Neurotoxic Shellfish Poison (NSP). Two species we found to be rejected produce either PSP (Gonyaulax tamarensis; Loeblich \& Loeblich 1979) or NSP (Ptychodiscus brevis; Baden \& Mende 1982, Risk et al. 1979). However, Gonyaulax catenella and $G$. acatenella also produce PSP (Loeblich \& Loeblich 1979), and they are not rejected. The toxicity of the 2 other rejected dinoflagellates, Protoceratium reticulatum and Scrippsiella trochoidea, has not been investigated

\section{Ecological and evolutionary significance}

Dinoflagellates which produce metabolites that inhibit predation gain an inter-specific competitive advantage that enhances their survival. Four of the 5 species or strains we found to be rejected are known to form monospecific blooms. What role might their chemical defense mechanisms play in structuring the ecosystem? How, specifically, could inhibitory metabolites affect a population of potential predators and encourage the formation of blooms? Finally, does the dinoflagellate pay a price for this defensive strategy?

Our results suggest that the direct and indirect effects of particle rejection can be disastrous for copepod grazers. For the copepod the reduced grazing rate supplies only enough energy to account for respiratory requirements. With minimal energy available, growth and reproduction cease. Starvation ensues and, if conditions persist, significant numbers of predators may die within days.

From the available information we postulate a series of events which could lead to the formation and concentration of monospecific blooms. These events could occur in concert with causative physical and biological factors which are already known (Steidinger 1983). The rejected dinoflagellate species must first be introduced into the water column. Even at relatively low concentrations their presence can begin to inhibit grazing, as indicated by our experiments with Protoceratium reticulatum. The growth of potential competitors can also be limited, as indicated by Freeberg et al. (1979), who found that filtrates of Ptychodiscus brevis cultures inhibited the growth of 18 out of 28 phytoplankters tested. With these mechanisms in force, the rejected dinoflagellate can continue to increase its own biomass while eliminating that of competitors. The primary effect of particle rejection is to immediately reduce predation pressure. Secondary effects of starvation, mortality, and suspended reproduction further reduce the grazing pressure - of both present and future generations of predators. The result is a monospecific bloom

These events occur on the appropriate time scale. Dinoflagellate blooms usually last for a period of several weeks (Malone 1978, Cullen et al. 1982, Steidinger 1983). This provides enough time to affect the population dynamics of numerically important copepod grazers such as Calanus pacificus, which has a generation time of 10 to $25 \mathrm{~d}$ (Huntley \& Brooks 1982), or Acartia clausi and $A$. tonsa, which have generation times of 10 to $20 \mathrm{~d}$ (Miller et al. 1977).

How widespread is the influence of such blooms, and how important are they? Red tides occur on a massive scale every year in the Inland Sea of Japan 
(Hashimoto 1979). Off the coast of Florida significant blooms of Ptychodiscus brevis occur, on average, about once every 2 yr (Steidinger \& Joyce 1973). In Southern California waters dinoflagellate blooms occurred in 17 of the 23 yr from 1952 to 1974 (Eppley \& Harrison 1975, Sweeney 1975, Holmes et al. 1967). Malone (1978) documented the occurrence of a bloom of Ceratium tripos which persisted for 6 mo of 1976 in a $10,000 \mathrm{~km}^{2}$ area of the New York Bight. Pelaez (1984) and Cullen et al. (1982) used a combination of satellite imagery and measurements at sea to document the occurrence of a bloom of Gymnodinium flavum, which dominated the phytoplankton for more than a month throughout much of the Southern California Bight. Furthermore, observations by Huntley (1982) showed that naturally occurring G. flavum cells from the bloom were rejected as food by the copepod, Calanus pacificus.

Avoidance of monospecific dinoflagellate blooms by zooplankton grazers may play a role in bloom maintenance. Fiedler (1982) observed that several species of zooplankton herbivores avoided a dense layer of Gymnodinium splendens off the coast of southern California, and that their grazing rates were significantly reduced within the layer. Furthermore, gut fullness of zooplankton within the layer was significantly lower within the layer than outside it. Huntley (1982) found the same result for the copepod Calanus pacificus in relation to a bloom of Gymnodinium flavum. The results of our feeding experiments with $G$. splendens do not agree with those of Fiedler (1982). We considered that our culture of $G$. splendens might have lost its activity since it had been maintained in the laboratory for more than $10 \mathrm{yr}$. Therefore, in June of 1983 we isolated a new strain of this species from local waters, allowed it only enough time to achieve logarithmic growth in a $1 \mathrm{l}$ culture, and then used it in a feeding experiment - even so, we failed to observe reduced grazing rates. We cannot explain why our laboratory observations should differ from those of Fiedler (1982). However, field observations suggest that zooplankton grazers may actually avoid high concentrations of phytoplankton. Hardy \& Gunther (1936) postulated in their 'exclusion hypothesis' that phytoplankton exude noxious substances which deter the aggregation of zooplankton predators. Our results with Protoceratium reticulatum suggest that the bioactive compound has its primary effect on feeding behavior, not on distribution. No effects on distribution were observed within $30 \mathrm{~min}$, yet changes in feeding behavior took place on that time scale. Thus, if zooplankton predators are excluded from high densities of dinoflagellates, then it may not be due to some chemical compound which immediately excludes them from the area, but rather because the zooplankton sample the food particles, find them unpalatable, and 'learn' to avoid the region.
Table 8. Rejected and non-rejected dinoflagellate species: a comparison of growth rates at 17 and $23^{\circ} \mathrm{C}$. Each growth rate determination was made on a separate generation, with measurements of culture density made daily for periods ranging from 5 to $21 \mathrm{~d}$. A 1 -tailed t-test showed that, at both temperatures, the growth rate of 'rejected' cells was significantly lower than growth rate of 'non-rejected' cells. Significance: $\cdots P<0.01$

\begin{tabular}{|c|c|c|}
\hline \multirow[t]{2}{*}{ Species } & \multicolumn{2}{|c|}{$\begin{array}{l}\text { Growth rate } \\
\text { (doublings } \mathrm{d}^{-1} \text { ) }\end{array}$} \\
\hline & $17^{\circ} \mathrm{C}$ & $23^{\circ} \mathrm{C}$ \\
\hline \multicolumn{3}{|l|}{ Not rejected } \\
\hline \multirow[t]{2}{*}{ Gonyaulax acatenella } & 0.141 & 0.276 \\
\hline & 0.268 & 0.278 \\
\hline \multirow[t]{5}{*}{ Gonyaulax catenella } & 0.296 & 0.283 \\
\hline & 0.292 & 0.303 \\
\hline & & 0.394 \\
\hline & & 0.382 \\
\hline & & 0.356 \\
\hline \multirow[t]{5}{*}{ Gonyaulax polyedra } & & 0.485 \\
\hline & & 0.447 \\
\hline & & 0.515 \\
\hline & & 0.453 \\
\hline & & 0.379 \\
\hline \multirow[t]{4}{*}{ Gyrodinium dorsum } & 0.270 & 0.232 \\
\hline & 0.220 & 0.219 \\
\hline & & 0.317 \\
\hline & & 0.202 \\
\hline \multirow[t]{5}{*}{ Gyrodinium resplendens } & 0.452 & 0.570 \\
\hline & 0.333 & 0.634 \\
\hline & 0.307 & 0.620 \\
\hline & & 0.413 \\
\hline & & 0.534 \\
\hline \multirow[t]{2}{*}{ Peridinium foliaceum } & 0.294 & 0.364 \\
\hline & 0.323 & $\begin{array}{l}0.555 \\
0.395\end{array}$ \\
\hline Mean: & 0.290 & 0.401 \\
\hline \multicolumn{3}{|l|}{ Rejected } \\
\hline \multirow{2}{*}{$\begin{array}{l}\text { Gonyaulax tamarensis ( } 429) \\
\text { Gonyaulax tamarensis (Ips) }\end{array}$} & & 0.206 \\
\hline & & 0.286 \\
\hline \multirow[t]{5}{*}{ Protoceratium reticulatum } & 0.131 & 0.227 \\
\hline & 0.108 & 0.257 \\
\hline & & 0.255 \\
\hline & & 0.218 \\
\hline & & 0.274 \\
\hline \multirow[t]{2}{*}{ Scrippsiella trochoidea } & 0.214 & 0.030 \\
\hline & 0.237 & 0.063 \\
\hline Mean: & $0.173^{\cdots}$ & $0.202 \cdots$ \\
\hline
\end{tabular}

This explanation is consistent with observations in both the laboratory and the field.

If rejected dinoflagellates are so successful at reducing predation and eliminating competition, then why do they not dominate the ocean's particulate matter? Dinoflagellates tend not to produce blooms in the turbulent environments which favor non-motile diatoms (Margalef et al. 1979), and they generally have slower growth rates than diatoms (Hoogenhout \& Amesz 
1965). These are the probable reasons why diatoms dominate spring blooms in temperate regions.

Why, then, do rejected dinoflagellates not dominate the phytoplankton at other times of year? The answer may be that it is because they have slower growth rates than other dinoflagellates. Table 8 shows the results of a comparison of growth rates, at both 17 and $23^{\circ} \mathrm{C}$, between rejected dinoflagellates and those which were not rejected in our experiments. The rejected species grow at significantly lower rates (approximately half the rate of non-rejected species), as indicated by the results of 1 -tailed t-tests at the $99 \%$ confidence level. Thus, the advantage of a chemical defense against predation appears to exact a compensatory cost, in the form of a reduced growth rate. We are not certain of (1) the nature of the chemical defense in the dinoflagellates we investigated, or (2) the cost (in energetic terms) of producing this defense. However, studies on terrestrial plants have shown that, in general, many secondary plant defensive substances are produced by anabolic, energy-demanding pathways (Rhoades 1979), and that such antiherbivore defense is costly to plants (e.g. Cates 1975, Tester 1977). The data on marine dinoflagellates shown in Table 8 is highly suggestive, but more information on the defensive compounds themselves is required to analyse their contribution to energy budgets.

Steidinger (1983) suggested that the so-called dinoflagellate toxins conferred a competitive advantage, and enquired why all species of dinoflagellates capable of forming monospecific blooms did not produce them. We suggest that it is not necessarily the dinoflagellate toxins which provide the means of chemical defense. The primary assay for PSP activity is a test of toxicity to mice (e.g. Collins 1978), which tells us little of its effect on pelagic predators. Furthermore, a dinoflagellate which lacks toxicity to mice may elaborate other metabolites which are effective inhibitors of predation. We know little or nothing about such bioactive compounds.

Acknowledgements. We thank J. Jordan, K.-G. Barthel, D. Gross and $C$. J. Tont for the many hours they spent with us conducting experiments and analysing samples. The Food Chain Research Group skiff provided invaluable and immediate access to live material. Dr. O. Holm-Hansen kindly shared his laboratory with us for many months, and Dr W. Fenical shared his knowledge and views on chemical aspects of the research. This work was supported, in part, by NSF grant OCE82-15903 awarded to Mark Huntley; the remainder was supported through significant voluntary contributions of time from all those involved.

\section{LITERATURE CITED}

Alldredge, A. L. (1981). The impact of appendicularian grazing on natural food concentrations in situ. Limnol. Oceanogr 26: $247-257$
Allen, W. E. (1941). Twenty years' statistical studies of marine plankton dinoflagellates of Southern California. Am. Midl. Nat. 26: 603-635

Anderson, D. M., Kulis, D., Orphanos, J., Cuervels, A. (1982). Distribution of the toxic dinoflagellate Gonyaulax tamarensis in the southern New England region. Estuar coast. Shelf Sci. 14: 447-458

Baden, D. G., Mende, T (1982). Toxicity of two toxins from the Florida red tide dinoflagellate, Ptychodiscus brevis. Toxicon 20: $457-461$

Baden, D. G., Mende, T., Lichter, W., Wellham, L. (1981). Crystallization and toxicology of T34: a major toxin from Florida's red tide organism (Ptychodiscus brevis). Toxicon 19: $455-462$

Barrientos, Chacon Y. (1980). Thesis, Univ. Ottawa. (Cited in Strickler 1982)

Bartram, W. (1980). Experimental development of a model for the feeding of neritic copepods on phytoplankton. J. Plankton Res. 3: 25-51

Cates, R. G. (1975). The interface between slugs and wild ginger some evolutionary aspects. Ecology 56: 391-400

Collins, M. (1978). Algal toxins Microbiol. Rev 1978: $725-746$

Conover, R. J. (1978). Transformation of organic matter. In: Kinne, O. (ed.) Marine ecology, Vol. IV, Dynamics. Wiley, Chichester, p. 221-499

Conover, R. J., Huntley, M. (1980). General rules of grazing in pelagic ecosystems. In: Falkowski, P. (ed.) Primary productivity in the sea. Plenum Press, New York, p. 461-485

Cullen, J., Horrigan, S., Huntley, M., Reid, F. M. H. (1982) Yellow water in La Jolla Bay, California, July 1980. I. A bloom of the dinoflagellate, Gymnodinium flavum Kofoid and Swezy. J. exp. mar Biol. Ecol. 63: 67-80

Donaghay, P., Small, L. (1979). Food selection capabilities of the estuarine copepod Acartia clausi. Mar Biol. 52: $137-146$

Eppley, R. W., Harrison, W G. (1975). Physiological ecology of Gonyaulax polyedra, a red water dinoflagellate of Southern California. In: LoCicero, $V$ (ed.) Proceedings of the first international conference on toxic dinoflagellate blooms, Mass. Science Technol. Foundation, Wakefield, Mass., p. 11-22

Fernandez, F. (1979). Particle selection in the nauplius of Calanus pacificus. J. Plankton Res. 1: 313-328

Fiedler, P. (1982). Zooplankton avoidance and reduced grazing responses to Gymnodinium splendens (Dinophyceae). Limnol. Oceanogr 27: 961-965

Freeberg, L, Marshall, A.. Heyl, M. (1979). Interrelationships of Gymnodinium breve (Florida red tide) within the phytoplankton community. In: Taylor, D. L., Seliger, H. H. (ed.) Toxic dinoflagellate blooms. Elsevier/North Holland, New York, p. 139-144

Friedman, M. M., Strickler, J. R. (1975). Chemoreceptors and feeding in calanoid copepods (Arthropoda: Crustacea). Proc. natn. Acad. Sci. U.S.A. 72: 4185-4188

Frost, B. W. (1972). Effects of the size and concentration of food particles on the feeding behavior of the marine planktonic copepod, Calanus pacificus. Limnol. Oceanogr 17: 805-815

Frost, B. W (1977). Feeding behavior of Calanus pacificus in mixtures of food particles. Limnol. Oceanogr 22: 472-491

Gifford, D., Bohrer, R., Boyd, C. M. (1981), Spines on diatoms: Do copepods care? Limnol. Oceanogr. 26: 971-981

Harbison, R., McAlister, V (1979). The filter-feeding rates and particles retention efficiencies of three species of Cyclosalpa (Tunicata, Thaliacea). Limnol. Oceanogr 24: 875-892 
Hardy, A., Gunther, E. R. (1936). The plankton of the South Georgia whaling grounds and adjacent waters, 1926-27. 'Discovery' Rep. 11: 1-456

Harris, R. P. (1982). Comparison of the feeding behavior of Calanus and Pseudocalanus in two experimentally manipulated enclosed ecosystems. J. mar biol. Ass. U. K. 62 : $71-91$

Hashimoto, Y (1979). Marine toxins and other bioactive marine metabolites, Jap. Sci. Societies Press, Tokyo

Holling, C. S. (1965). The functional response of predators to prey density and its role in mimicry and population regulation. Mem. ent. Soc. Can. 45: 1-60

Holmes, R., Williams, P., Eppley, R. (1967). Red water in La Jolla Bay, 1964-1966. Limnol. Oceanogr. 12: 503-512

Hoogenhout, H., Amesz, J. (1965). Growth rates of photosynthetic microorganisms in laboratory cultures. Arch. Mikrobiol. 50: 10-24

Huntley, M. E. (1982). Yellow water in La Jolla Bay, California, July 1980. II. Suppression of zooplankton grazing. J. exp. mar. Biol Ecol. 63: 81-91

Huntley, M., Brooks, E. R. (1982). Effects of age and food availability on diel vertical migration behavior of Calanus pacificus. Mar. Biol. 71: 23-31

Huntley, M. E., Barthel, K.-G., Star, J. L. (1983). Particle rejection by Calanus pacificus: Discrimination between similarly sized particles. Mar. Biol. 74: 151-160

Huntley, M., Boyd, C. M. (1984). Food-limited growth of marine zooplankton. Am. Nat. 124: 453-477

Ives, J. D. (in press). The relationship between Gonyaulax tamarensis cell toxin levels and copepod ingestion rates. In: Anderson, D. M., White, A. M., Baden, D. (ed.) Toxic dinoflagellate blooms.

Iizuka, S. (1975). On occurrence of similar organisms to Gymnodinium breve Davis in Omura Bay. Bull. Plankton Soc. Japan 21: 45-48

Koehl, M., Strickler, J. R. (1981). Copepod feeding currents: food capture at low Reynolds number Limnol. Oceanogr. 26: $1062-1073$

Lam, R. K., Frost, B. W. (1976). Model of copepod filtering response to changes in the size and concentration of food. Limnol. Oceanogr. 21: 490-500

Lin, Y.-Y., Risk, M., Ray, S. M., Van Engen, D., Clardy, J., Golik, J., James, J. C., Nakanishi, K. (1981). Isolation and structure of Brevetoxin B from the 'red tide' dinoflagellate Ptychodiscus brevis (Gymnodinium breve). J. Am. chem. Soc. 103: 6773-6775

Loeblich, III, A. R. (1975). A seawater medium for dinoflagellates and the nutrition of Cachonina niei. J. Phycol. 11: $80-86$

Loeblich, III, A., Loeblich, L. A. (1979). The systematics of Gonyaulax with special reference to the toxic species. In: Taylor, D., Seliger, H. H. (ed.) Toxic dinoflagellate blooms. Elsevier/North Holland, New York, p. 235-238

Lovegrove, T. (1962). The effect of various factors on dry weight vàlues. Rapp. P.-v. Réun Cons. perm. int. Explor. Mer. 153: 86-91

Lund, J. W., Kipling, C., LeCren, E. D. (1958). The inverted microscope method of estimating algal numbers and the statistical basis of estimations by counting. Hydrobiologia 11: $143-170$

Malone, T. (1978). The 1976 Ceratium tripos bloom in the New York Bight: Causes and consequences. NOAA Technical Report NMFS Circular 410, p. 1-14

Margalef, R., Estrada, M., Blasco, D. (1979). Functional morphology of organisms involved in red tides, as adapted to decaying turbulence. In: Taylor, D. L., Seliger, H. H. (ed.)
Toxic dinoflagellate blooms. Elsevier/North Holland New York, p. 89-94

Marin, V., Huntley, M., Frost, B. (in press). Measuring feeding rates of pelagic herbivores: analysis of experimental design and methods. Mar Biol.

Miller, C. B., Johnson, J. K., Heinle, J. R. (1977). Growth rules in the marine copepod genus Acartia. Limnol. Oceanogr. 22: $326-335$

Mullin, M. (1963). Some factors affecting the feeding of marine copepods of the genus Calanus. Limnol. Oceanogr 8: $239-250$

Murphy, E., Steidinger, K., Roberts, B., Williams, J., Jolley, Jr, J. (1975). An explanation for the Florida east coast Gymnodinium breve red tide of November, 1972. Limnol. Oceanogr. 20: 481-486

Ong, J. E. (1969). The fine structure of the mandibular sensory receptors in the brackish water copepod Gladioferens pectinatus. Z. Zellforsch. mikrosk. Anat. 97: 178-195

Paffenhöfer, G.-A., Strickler, J. R., Alcaraz, M. (1982). Suspension-feeding by herbivorous calanoid copepods: A cinematographic study. Mar. Biol. 67: 193-199

Parsons, T., LeBrasseur, R., Fulton, J. D. (1967). Some observations on the dependence of zooplankton grazing on the cell size and concentration of phytoplankton blooms. J. oceanogr. Soc. Japan 23: 10-17

Pelaez, J. (1984). Phytoplankton pigment concentrations and patterns in the California Current as determined by satellite. Ph. D. thesis, Univ. Calif., San Diego

Poulet, S. A., Marsot, P. (1978). Chemosensory grazing by marine calanoid copepods (Arthropoda: Crustacea). Science 200: 1403-1405

Rhoades, D. F. (1979). Evolution of plant chemical defense against herbivores. In: Rosenthal, G. A., Janzen, D. H. (ed.) Herbivores: their interaction with plant secondary metabolites. Academic Press, New York, p. 3-54

Risk, M., Lin, Y Y., McFarlane, R. D., Ramunujam, V., Smith, L. I. Trieff, N. M. (1979). Purification and chemical studies on a major toxin from Gymnodinium breve. In: Taylor, D. L., Seliger, H. H. (ed.) Toxic dinoflagellate blooms. Elsevier/North Holland, New York, p. 335-344

Runge, J. A. (1980). Effects of hunger and season on the feeding behavior of Calanus pacificus. Limnol. Oceanogr 26: $134-145$

Sharp, J. (1974). Improved analysis for 'particulate' carbon and nitrogen from seawater. Limnol. Oceanogr 19: 984-989

Sokal, R. R., Rohlf, F. J. (1981). Biometry. W. H. Freeman, San Francisco

Steele, J., Mullin, M. M. (1977). Zooplankton dynamics. In: Goldberg, E. D. (ed.) The sea, Vol. 6. Wiley-Interscience, New York, p. 857-890

Steidinger, K. A. (1983). A re-evaluation of toxic dinoflagellate biology and ecology. Prog. Phycol. Res. 2: 147-188

Steidinger, K., Joyce, E. A. (1973). Florida red tides. Fla. Dep. Nat. Resources. Mar. Lab. Educ. Ser. No. 17, p. 1-26

Sweeney, B. (1975). Red tides I have known. In: LoCicero, V (ed.) Proceedings of the first international conference on toxic dinoflagellate blooms. Mass. Science Technol. Foundation, Wakefield, Mass., p. 225-234

Strickler, J. R. (1982). Calanoid copepods, feeding currents, and the role of gravity. Science 218: $158-160$

Tester, C. F. (1977). Constituents of soybean cultivars differing in insect resistance. Phytochemistry 16: 1899-1901

Vinogradov, M. (1970). Vertical distribution of the oceanic zooplankton. Keter, Jerusalem (Israel program for scientific translations) 
Williams, P. J. LeB. (1981). Incorporation of microheterotrophic processes in the classical paradigm of the planktonic food web. Kieler Meeresforsch. 5: 1-28
Wood, E. J. F. (1968). Dinoflagellates of the Caribbean Sea and adjacent areas. Univ. Miami Press, Coral Gables

This paper was presented by Dr R. Lasker; it was accepted for printing on October 4, 1985 